\title{
Inhibitory Effect of Methyleugenol on IgE-Mediated Allergic Inflammation in RBL-2H3 Cells
}

\author{
Feng Tang, ${ }^{1,2}$ Feilong Chen, ${ }^{1,2}$ Xiao Ling, ${ }^{1,2}$ Yao Huang, ${ }^{1,2}$ \\ Xiaomei Zheng, ${ }^{1,2}$ Qingfa Tang, ${ }^{1,2}$ and Xiaomei Tan ${ }^{1,2}$ \\ ${ }^{1}$ School of Traditional Chinese Medical Sciences, Southern Medical University, Guangzhou 510515, China \\ ${ }^{2}$ Guangdong Province Key Laboratory of Chinese Medicine Pharmaceutics, Southern Medical University, Guangzhou 510515, China
}

Correspondence should be addressed to Qingfa Tang; tangqf96@163.com and Xiaomei Tan; tanxm_smu@163.com

Received 23 December 2014; Revised 16 February 2015; Accepted 18 February 2015

Academic Editor: Lifei Hou

Copyright (C) 2015 Feng Tang et al. This is an open access article distributed under the Creative Commons Attribution License, which permits unrestricted use, distribution, and reproduction in any medium, provided the original work is properly cited.

\begin{abstract}
Allergic diseases, such as asthma and allergic rhinitis, are common. Therefore, the discovery of therapeutic drugs for these conditions is essential. Methyleugenol (ME) is a natural compound with antiallergic, antianaphylactic, antinociceptive, and antiinflammatory effects. This study examined the antiallergic effect of ME on IgE-mediated inflammatory responses and its antiallergy mechanism in the mast cell line, RBL-2H3. We found that ME significantly inhibited the release of $\beta$-hexosaminidase, tumor necrosis factor- (TNF-) $\alpha$, and interleukin- (IL-) 4, and was not cytotoxic at the tested concentrations (0-100 $\mu \mathrm{M})$. Additionally, ME markedly reduced the production of the proinflammatory lipid mediators prostaglandin $\mathrm{E}_{2}\left(\mathrm{PGE}_{2}\right)$, prostaglandin $\mathrm{D}_{2}\left(\mathrm{PGD}_{2}\right)$, leukotriene $\mathrm{B}_{4}\left(\mathrm{LTB}_{4}\right)$, and leukotriene $\mathrm{C}_{4}\left(\mathrm{LTC}_{4}\right)$. We further evaluated the effect of ME on the early stages of the FceRI cascade. ME significantly inhibited Syk phosphorylation and expression but had no effect on Lyn. Furthermore, it suppressed ERK1/2, p38, and JNK phosphorylation, which is implicated in proinflammatory cytokine expression. ME also decreased cytosolic phospholipase $\mathrm{A}_{2}\left(\mathrm{CPLA}_{2}\right)$ and 5-lipoxygenase (5-LO) phosphorylation and cyclooxygenase-2 (COX-2) expression. These results suggest that $\mathrm{ME}$ inhibits allergic response by suppressing the activation of Syk, ERK1/2, p38, JNK, cPLA 2 , and 5-LO. Furthermore, the strong inhibition of COX-2 expression may also contribute to the antiallergic action of ME. Our study provides further information about the biological functions of ME.
\end{abstract}

\section{Introduction}

Allergic airway diseases, such as asthma and allergic rhinitis, are common diseases caused by hypersensitivity of the immune system. Approximately $10-20 \%$ of the world population is affected by allergies, with the number of allergy patients increasing annually $[1,2]$. Most allergy patients are genetically predisposed to produce IgE. Mast cells are a key player in early allergic response, which typically occurs within minutes of exposure to an appropriate antigen, and other biological responses, including inflammatory disorders [3]. These cells are critical effector cells in IgE-dependent immediate hypersensitivity reactions [4]. Mast cell degranulation can initiate an acute inflammatory response and contribute to the progression of chronic diseases [5]. When an IgE-antigen binds with FceRI, the receptor is activated, and a variety of biologically active mediators are released, causing allergic reactions, including the release of $\beta$-hexosaminidase, a common degranulation marker, histamine, arachidonic acid metabolites, and inflammatory cytokines [6]. Importantly, arachidonic acid metabolites, including prostaglandins and leukotrienes, mediate acute and chronic allergic reactions $[7,8]$. RBL-2H3 cells are a mast cell line that originated from rat basophilic leukemia and have been widely used to study IgE-FceRI interactions and degranulation. Furthermore, RBL-2H3 cells are a useful model for in vitro screening of antiallergy drug candidates.

The MAP kinase cascade is an important signaling pathway that regulates the differentiation, activation, proliferation, degranulation, and migration of immune cells, including mast cells [9]. MAPK signaling molecules are divided into three groups: extracellular signal-regulated kinase (ERK) $1 / 2$, p38 MAPK, and c-JunNH2-terminal kinase (JNK) 1/2. Erk1/2 
is an essential signal in the production of interleukin- (IL-) 5 , tumor necrosis factor- (TNF-) $\alpha$, IL-3, and IL-13 in mast cells [10]. p38 MAP kinase stimulates IL-4 production in bone marrow mast cells (BMMCs) [11]. Additionally, the activation of JNK is also responsible, at least partially, for the expression and production of several cytokines, including TNF- $\alpha$, IL-2, and IL-6 in mast cells [12, 13].

Methyleugenol (ME,1-allyl-3,4-dimethoxybenzene) is an analog of the phenolic compound eugenol, and it is found in essential oils, including basil, anise, clove, lemon grass, and laurel leaf oils. In East Asia, ME is found in the essential oil fraction of Asiasari radix (Xixin in Chinese). It is used as a flavoring substance in dietary products, including cookies, ice cream, and nonalcoholic beverages, and is found in cosmetics, shampoos, soaps, fragrances, and herbal products in Europe, the USA, and other countries [14]. Previous work indicates that ME exerts antiallergic [15], antispasmodic [16], antinociceptive [14], and anti-inflammatory [17] effects. It was reported that ME inhibited passive cutaneous anaphylaxis (PCA) in rats, release of 5-lipoxygenase (5-LO) from RBL-1 cells and leukotriene $\mathrm{D}_{4}\left(\mathrm{LTD}_{4}\right)$ induced constriction of guinea pig ileum. ME also inhibited compound 48/80induced systemic anaphylaxis and antidinitrophenyl IgEinduced local anaphylaxis in mice [18]. However, the effects of $\mathrm{ME}$ on allergic response in IgE-activated RBL-2H3 cells and its antiallergic mechanism remain unknown.

In this study, we investigated the antiallergic effects of $\mathrm{ME}$ in IgE-activated RBL-2H3 cells. Furthermore, we evaluated the mechanisms responsible for the antiallergic effects of ME.

\section{Materials and Methods}

2.1. Reagents. ME was purchased from the National Institute for Food and Drug Control (Beijing, China; purity, $\geq 99.5 \%$ ). Dulbecco's minimum essential medium (DMEM), penicillin, streptomycin, and fetal bovine serum (FBS) were purchased from GIBCO (Grand Island, NY, USA). 4-[3-(4-Iodophenyl)2-4(4-nitrophenyl)-2H-5-tetrazolio]-1,3-benzene disulfonate (WST-1) was obtained from Dojindo (Kumamoto, Japan). Specific antibodies against phospho-Lyn, Lyn, phospho-Syk, Syk, phospho-ERK1/2, ERK1/2, phospho-p38, p38, phosphoJNK, JNK, cytosolic phospholipase $\mathrm{A}_{2}\left(\mathrm{cPLA}_{2}\right)$, phospho$\mathrm{cPLA}_{2}$, cyclooxygenase-2 (COX-2), and $\beta$-actin were purchased from Cell Signaling Technology (Beverly, MA, USA). Specific antibodies against phospho-5-lipoxygenase (5-LO) and 5-LO, and enzyme immunoassay (EIA) kits for prostaglandin $\mathrm{E}_{2}\left(\mathrm{PGE}_{2}\right)$, prostaglandin $\mathrm{D}_{2}\left(\mathrm{PGD}_{2}\right)$, leukotriene $\mathrm{B}_{4}\left(\mathrm{LTB}_{4}\right)$, and leukotriene $\mathrm{C}_{4}\left(\mathrm{LTC}_{4}\right)$ were purchased from Cayman Chemical (Ann Arbor, MI, USA). The enzyme-linked immunosorbent assay (ELISA) kits for TNF- $\alpha$ and IL-4 were obtained from Bangyi Technologies Inc. (Shanghai, China). Dinitrophenyl- (DNP-) IgE was obtained from Sigma-Aldrich (St. Louis, MO, USA), and DNP-bovine serum albumin (BSA) was obtained from Biosearch Technologies Inc. (Novato, CA, USA). All other chemicals were of analytical grade and were purchased from Sigma-Aldrich.
2.2. Cell Culture. RBL-2H3 cells were purchased from the Type Culture Collection of the Chinese Academy of Sciences (Shanghai, China). Cells were cultured in DMEM medium supplemented with $10 \%$ FBS and antibiotics $(100 \mathrm{U} / \mathrm{mL}$ penicillin and $100 \mu \mathrm{g} / \mathrm{mL}$ streptomycin) at $37^{\circ} \mathrm{C}$ in a humidified $5 \% \mathrm{CO}_{2}$ atmosphere.

2.3. Cytotoxicity Assay. Cell respiration served as an indicator of cell viability and was determined by measuring the mitochondrial-dependent reduction of WST-1 to watersoluble tetrazolium salt [19]. Briefly, RBL-2H3 cells were seeded onto a 96-well plate $\left(1 \times 10^{4}\right.$ cells/well $)$ in DMEM with $10 \% \mathrm{FBS}$ at $37^{\circ} \mathrm{C}$ overnight. The cells were washed and incubated with DNP-IgE $(10 \mu \mathrm{g} / \mathrm{mL})$ for $24 \mathrm{~h}$. The IgEsensitized cells were incubated with $\mathrm{ME}(0-100 \mu \mathrm{M})$ for $1 \mathrm{~h}$ and stimulated with DNP-BSA (100 ng/mL) for $4 \mathrm{~h}$. WST1 reagent $(10 \mu \mathrm{L})$ was added, and the mixture was further incubated for $1 \mathrm{~h}$. Cell viability was determined by measuring the difference in absorbance at a wavelength of $450 \mathrm{~nm}$.

2.4. $\beta$-Hexosaminidase Release Activity. RBL-2H3 cells were incubated in a 24 -well plate $\left(2 \times 10^{5}\right.$ cells/well $)$ at $37^{\circ} \mathrm{C}$ overnight. The cells were washed with $1 \times$ PBS and incubated with DNP-IgE $(10 \mu \mathrm{g} / \mathrm{mL})$ for $24 \mathrm{~h}$. The IgE-sensitized cells were incubated with $\mathrm{ME}(0-100 \mu \mathrm{M})$ for $1 \mathrm{~h}$, followed by $4 \mathrm{~h}$ incubation with DNP-BSA $(100 \mathrm{ng} / \mathrm{mL})$. To measure $\beta$ hexosaminidase activity, the culture medium was centrifuged $(17,000 \times \mathrm{g}, 10 \mathrm{~min})$ at $4^{\circ} \mathrm{C}$. The supernatant $(25 \mu \mathrm{L})$ was mixed with $10 \mathrm{mM}$ poly-N-acetyl glucosamine (p-NAG; $50 \mu \mathrm{L}$ ) in $0.1 \mathrm{M}$ sodium citrate buffer $(\mathrm{pH} 4.5)$ in a 96-well plate and incubated for $1 \mathrm{~h}$ at $37^{\circ} \mathrm{C}$. The reaction was terminated by stop buffer (0.1 $\mathrm{M} \mathrm{Na}_{2} \mathrm{CO}_{3}$ buffer, $\left.\mathrm{pH} 10.0\right)$. The $\beta$-hexosaminidase activity was determined by measuring the difference in absorbance at $405 \mathrm{~nm}$. Data were displayed as the mean \pm standard deviation (SD) of triplicate experiments.

2.5. ELISA. To measure the TNF- $\alpha$ and IL- 4 concentrations in the culture media, all samples were centrifuged $(17,000 \times \mathrm{g}$, $10 \mathrm{~min})$ at $4^{\circ} \mathrm{C}$ and stored at $-80^{\circ} \mathrm{C}$ until analysis. The TNF$\alpha$ and IL- 4 concentrations were measured using ELISA kits according to the manufacturer's instructions. Data were displayed as the mean \pm SD of triplicate experiments.

2.6. EIA. To determine the $\mathrm{PGE}_{2}, \mathrm{PGD}_{2}, \mathrm{LTB}_{4}$, and $\mathrm{LTC}_{4}$ concentrations in the culture media, all samples were centrifuged $(17,000 \times \mathrm{g}$ for $10 \mathrm{~min})$ at $4^{\circ} \mathrm{C}$, and the supernatant was stored at $-80^{\circ} \mathrm{C}$ until analysis. The $\mathrm{PGE}_{2}, \mathrm{PGD}_{2}, \mathrm{LTB}_{4}$, and $\mathrm{LTC}_{4}$ concentrations were measured with EIA kits according to the manufacturer's instructions. Data were displayed as the mean \pm SD of triplicate experiments.

2.7. Western Blot Analysis. RBL-2H3 cells were seeded onto a 6 -well plate $\left(5 \times 10^{5}\right.$ cells/well $)$ in DMEM with $10 \% \mathrm{FBS}$ at $37^{\circ} \mathrm{C}$ overnight. The cells were washed and incubated with DNP-IgE $(10 \mu \mathrm{g} / \mathrm{mL})$ for $24 \mathrm{~h}$. The cells were then incubated in $\mathrm{ME}(0-100 \mu \mathrm{M})$ for $1 \mathrm{~h}$ and stimulated with DNP-BSA $(100 \mathrm{ng} / \mathrm{mL})$ for $4 \mathrm{~h}$. The harvested cells were lysed, and the target protein was resuspended in protein lysis buffer. 


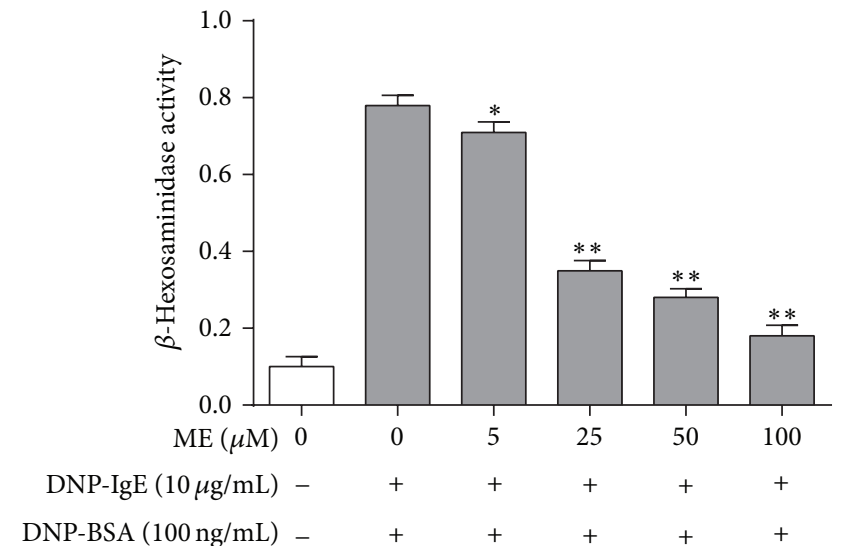

(a)

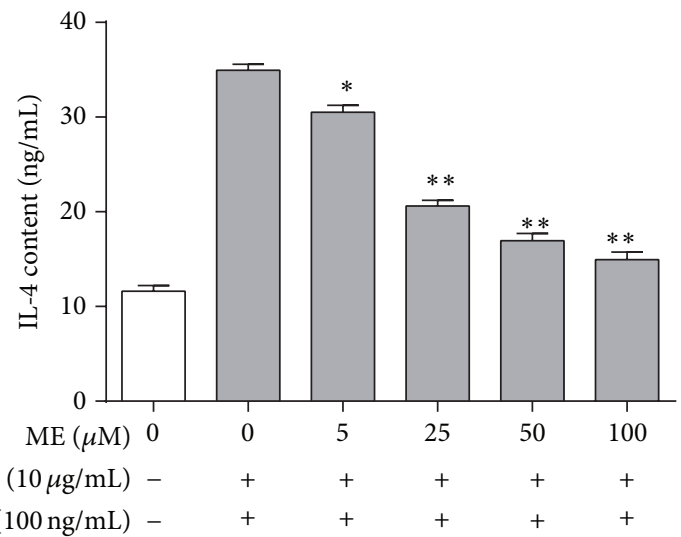

(c)

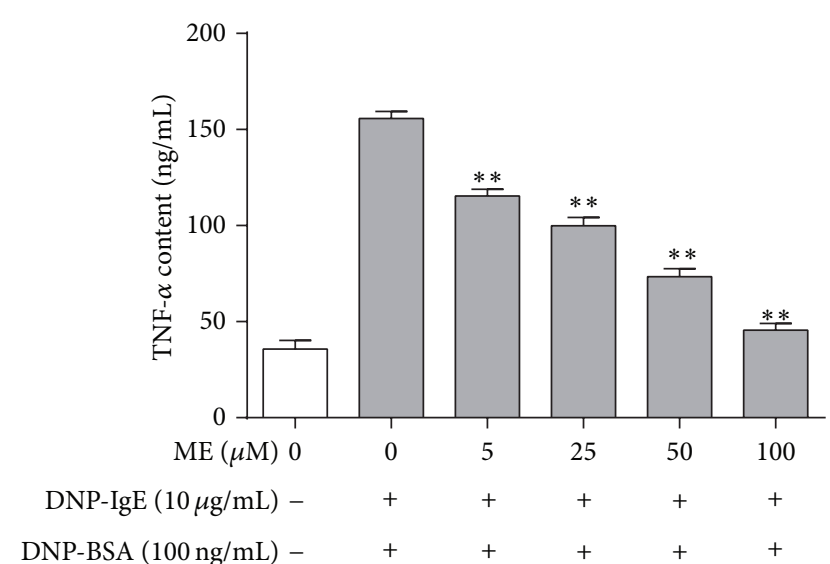

(b)

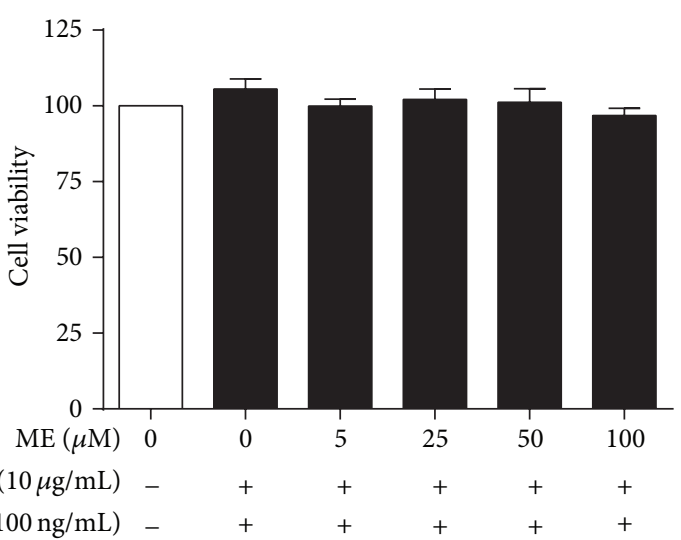

(d)

FIGURE 1: Effect of ME on activity of $\beta$-hexosaminidase and level of TNF- $\alpha$, IL- 4 released in IgE-activated RBL-2H3 cells. RBL-2H3 cells were seeded on a 24 -well plate in DMEM with $10 \% \mathrm{FBS}$ at $37^{\circ} \mathrm{C}$ overnight, and then the cells were washed and further incubated with DNP-IgE for $24 \mathrm{~h}$. The cells were incubated with $\mathrm{ME}(0-100 \mu \mathrm{M})$ for $1 \mathrm{~h}$ and then stimulated by DNP-BSA $(100 \mathrm{ng} / \mathrm{mL})$ for $4 \mathrm{~h}$. $\beta$-Hexosaminidase activity (a) and TNF- $\alpha$ level (b) and IL-4 level (c) were determined as described in Section 2. RBL-2H3 cells were seeded on a 96-well plate (2.5 $\times$ $10^{4}$ cells/well) in DMEM with $10 \% \mathrm{FBS}$ at $37^{\circ} \mathrm{C}$ overnight, and then the cells were washed and further incubated with DNP-IgE for $24 \mathrm{~h}$. The cells were incubated with ME $(0-100 \mu \mathrm{M})$ for $1 \mathrm{~h}$, simultaneously treated with DNP-BSA $(100 \mathrm{ng} / \mathrm{mL})$ and WST-1 reagent $(10 \mu \mathrm{L})$, and then incubated for $4 \mathrm{~h}$. Cell viability (d) was determined as described in Section 2. Data represent the mean \pm SD of three independent experiments and differences between mean values were assessed by one-way ANOVA. ${ }^{*} P<0.05,{ }^{* *} P<0.01$ indicate significant differences compared with the DNP-BSA-treated group.

The cell lysates were separated by sodium dodecyl sulfatepolyacrylamide gel electrophoresis (SDS-PAGE) and transferred to polyvinylidene fluoride (PVDF) membranes. The membranes were then incubated with a 1:1,000 dilution of specific antibodies against phospho-Lyn, Lyn, phospho-Syk, Syk, phospho-ERK1/2, ERK1/2, phospho-p38, p38, phosphoJNK, JNK, phospho-cPLA $2, \mathrm{CPLA}_{2}, \mathrm{COX}-2$, and $\beta$-actin and antibodies against phospho-5-LO and 5-LO. The blots were washed with TBS-T and incubated in a 1:5,000 dilution of horseradish peroxidase-conjugated IgG secondary antibodies. The proteins on the membranes were detected using a chemiluminescent reaction, and the membranes were exposed to Hyperfilm ECL. The target protein concentrations were compared to the control concentrations, and the results for each protein were expressed as a density ratio based on a protein standard size marker. The density of each band was determined using ImageJ software.
2.8. Statistical Analysis. The results were expressed as mean \pm standard deviation (SD) and differences between mean values of normally distributed data were assessed by the oneway analysis of variance (ANOVA) followed by Duncan's test for multiple comparisons. $P$ values of 0.05 or 0.01 were considered statistically significant.

\section{Results}

3.1. Inhibitory Effect of ME on IgE-Mediated Allergic Response in $\mathrm{RBL}-2 \mathrm{H} 3$ Cells. To determine the optimal concentrations of $\mathrm{ME}$ for our study, we assessed the cytotoxicity of $\mathrm{ME}$ and antigen (DNP-BSA) cotreatment. We treated the RBL-2H3 mast cells with ME concentrations ranging from 1 to $100 \mu \mathrm{M}$ in subsequent experiments. The IgEsensitized RBL-2H3 cells were exposed to ME at various concentrations $(0-100 \mu \mathrm{M})$ for $1 \mathrm{~h}$ and stimulated with 


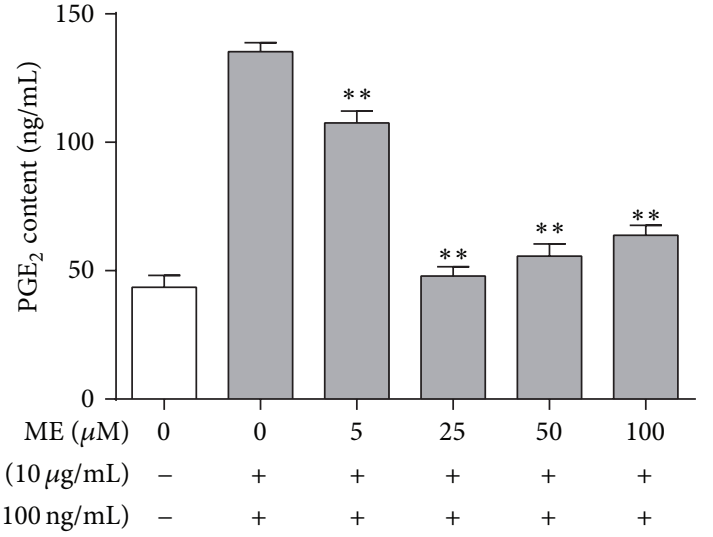

(a)

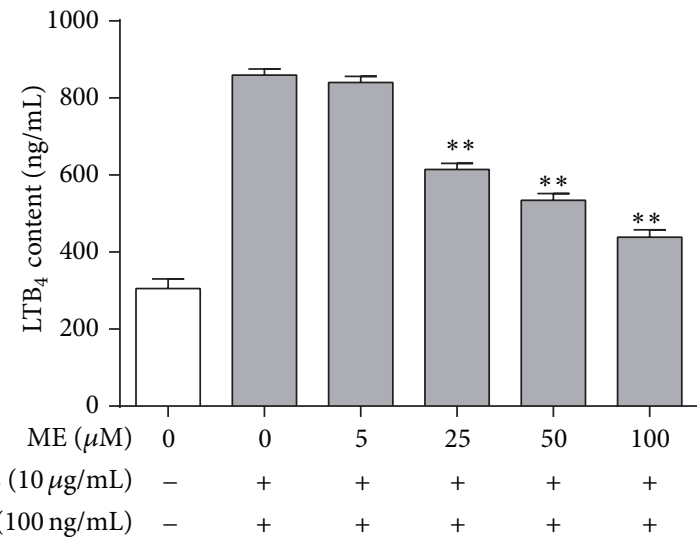

(c)

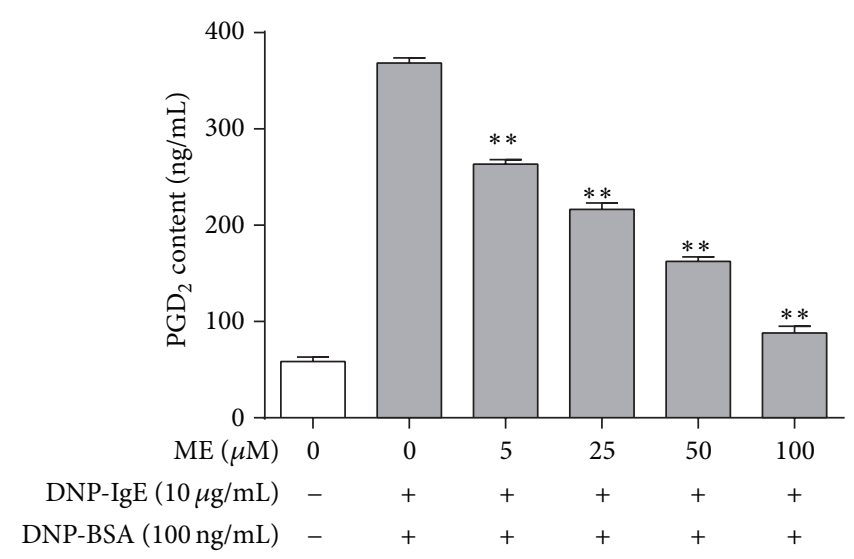

(b)

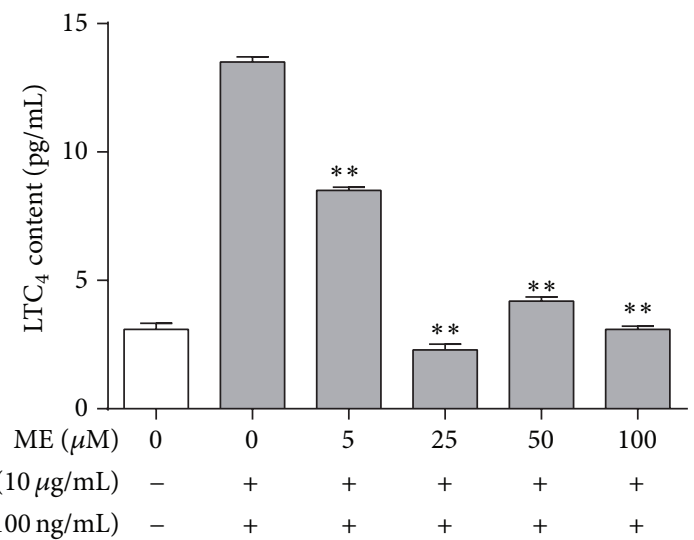

(d)

FIGURE 2: Effect of ME on formation of $\mathrm{PGE}_{2}, \mathrm{PGD}_{2}, \mathrm{LTB}_{4}$, and $\mathrm{LTC}_{4}$ in IgE-activated RBL-2H3 cells. RBL-2H3 cells were seeded on a 24-well plate in DMEM with $10 \% \mathrm{FBS}$ at $37^{\circ} \mathrm{C}$ overnight, and then the cells were washed and further incubated with DNP-IgE for $24 \mathrm{~h}$. The cells were incubated with ME $(0-100 \mu \mathrm{M})$ for $1 \mathrm{~h}$ and then stimulated by DNP-BSA for $4 \mathrm{~h}$. The amounts of $\mathrm{PGE}_{2}(\mathrm{a}), \mathrm{PGD}_{2}(\mathrm{~b}), \mathrm{LTB}_{4}(\mathrm{c})$, and LTC $\mathrm{LT}_{4}(\mathrm{~d})$ were determined as described in Section 2. Data represent the mean \pm SD of three independent experiments and differences between mean values were assessed by one-way ANOVA. ${ }^{*} P<0.05,{ }^{* *} P<0.01$ indicate significant differences compared with the DNP-BSA-treated group.

$100 \mathrm{ng} / \mathrm{mL}$ DNP-BSA for $4 \mathrm{~h}$ for the $\beta$-hexosaminidase assay. ME markedly inhibited the release of $\beta$-hexosaminidase (Figure 1(a)), which is a general biomarker of degranulation and a hallmark characteristic of allergic reactions caused by allergen exposure. Additionally, the release of TNF$\alpha$ and IL-4, two proinflammatory cytokines, from RBL$2 \mathrm{H} 3$ cells was markedly suppressed by $\mathrm{ME}$ in a dosedependent manner (Figures 1(b) and 1(c)). ME treatment $(0-100 \mu \mathrm{M})$ for $24 \mathrm{~h}$ produced no significant cytotoxic effect (Figure 1(d)).

\subsection{Inhibitory Effects of ME on the Formation of Proinflam-} matory Lipid Mediators. We next examined the effect of $\mathrm{ME}$ on the formation of $\mathrm{PGE}_{2}, \mathrm{PGD}_{2}, \mathrm{LTB}_{4}$, and $\mathrm{LTC}_{4}$, which are proinflammatory lipid mediators that regulate allergic response [20-23] produced via arachidonate signaling downstream of IgE-mediated FceRI activation [24]. RBL-2H3 cells were preincubated with $\mathrm{ME}(0-100 \mu \mathrm{M})$ prior to antigen challenge, and the formation of $\mathrm{PGE}_{2}, \mathrm{PGD}_{2}, \mathrm{LTB}_{4}$, and $\mathrm{LTC}_{4}$ was measured by EIA assay. As shown in Figure 2, $\mathrm{ME}$ markedly inhibited the formation of $\mathrm{PGE}_{2}, \mathrm{PGD}_{2}$, and
$\mathrm{LTC}_{4}$ and suppressed $\mathrm{LTB}_{4}$ formation to a lesser extent. Collectively, these results suggest that $\mathrm{ME}$ suppresses allergic inflammation induced by $\mathrm{PGE}_{2}, \mathrm{PGD}_{2}, \mathrm{LTB}_{4}$, and $\mathrm{LTC}_{4}$. This indicates that $\mathrm{ME}$ directly inhibits an enzyme involved in prostaglandin and leukotriene biosynthesis.

3.3. Regulatory Effects of ME on Enzymes Associated with the Arachidonate Cascade. We additionally investigated the antiallergic effects of ME on the activation of enzymes in the arachidonate cascade. Arachidonate cascade activation has been implicated in FceRI receptor activation in IgE-activated mast cells [22]. Therefore, we hypothesized that ME, which showed antiallergic effects, would affect $c \mathrm{PLA}_{2}, 5-\mathrm{LO}$, or COX-2 activation (Figure 3 ). When the IgE-sensitized RBL$2 \mathrm{H} 3$ cells were exposed to $\mathrm{ME}$ at various concentrations for $1 \mathrm{~h}$ prior to antigen stimulation, phosphorylation of $\mathrm{CPLA}_{2}$, the rate-limiting step of the arachidonate cascade, was diminished. Similarly, ME suppressed 5-LO phosphorylation, the rate-limiting step of leukotriene biosynthesis, and inhibited COX-2 expression, which catalyzes the rate-limiting step of prostaglandin biosynthesis. These findings indicate that $\mathrm{ME}$ 


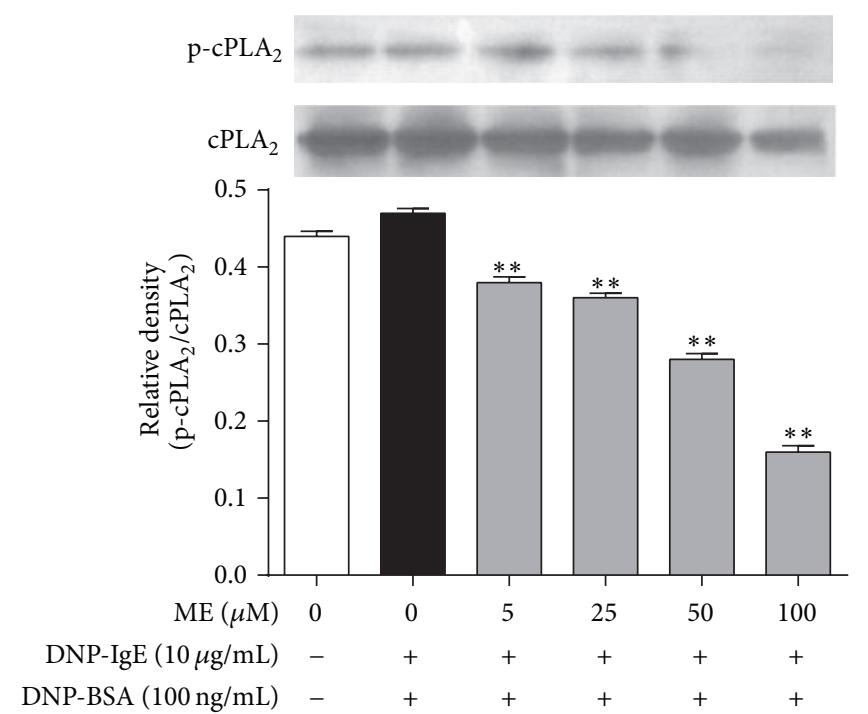

(a)

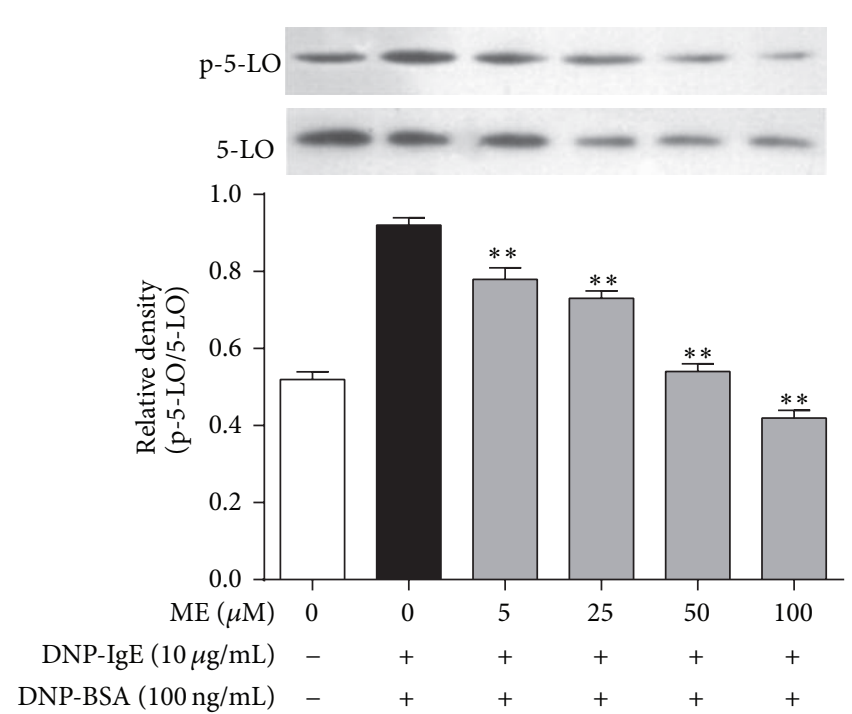

(b)

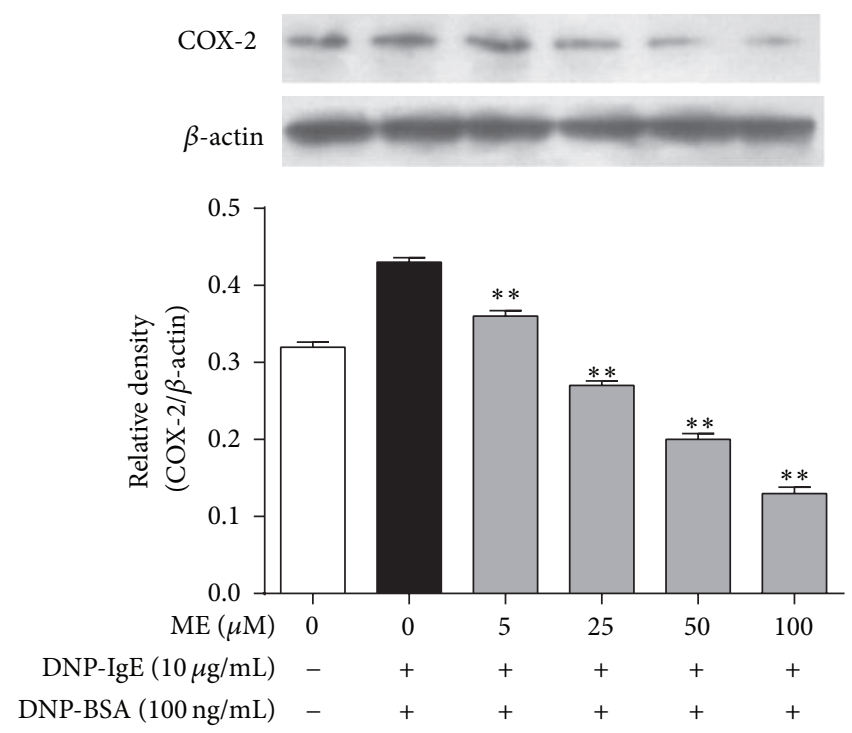

(c)

Figure 3: Effect of ME on a late stage of the FceRI signal cascade in IgE-activated RBL-2H3 cells. RBL-2H3 cells were seeded on a 6-well plate in DMEM with $10 \% \mathrm{FBS}$ at $37^{\circ} \mathrm{C}$ overnight, and then the cells were washed and further incubated with DNP-IgE for $24 \mathrm{~h}$. The cells were incubated with ME $(0-100 \mu \mathrm{M})$ for $1 \mathrm{~h}$ and then stimulated by DNP-BSA for $4 \mathrm{~h}$. The cells were rinsed and lysed with a cell lysis buffer. The expression of $\mathrm{p}-\mathrm{CPLA}_{2}, \mathrm{cPLA}_{2}, \mathrm{p}$-5-LO, 5-LO, COX-2, and $\beta$-actin was determined as described in Section 2 . Data represent the mean \pm SD of three independent experiments and differences between mean values were assessed by one-way ANOVA. ${ }^{*} P<0.05,{ }^{* *} P<0.01$ indicate significant differences compared with the DNP-BSA-treated group.

decreases the activation of several targets, including $\mathrm{CPLA}_{2}$, $5-\mathrm{LO}$, and COX-2, suggesting that the antiallergic action of ME may be mediated by arachidonate cascade suppression.

3.4. Suppressive Effect of ME on FceRI Signaling Pathway. Next, we investigated the mechanism of the antiallergic action of ME. Activation of the FceRI receptor induces Lyn and Syk phosphorylation, mediating the degranulation of mast cells [22]. In this respect, ME may affect Lyn or Syk phosphorylation in the early phase of the FceRI receptor cascade. When RBL-2H3 cells were preincubated with ME for $1 \mathrm{~h}$ before antigen challenge, and the incubation was extended an additional $10 \mathrm{~min}$, the phosphorylation of Syk, but not Lyn, was inhibited in a dose-dependent manner (Figure 4). Notably, ME markedly reduced the expression and phosphorylation of ERK1/2 (Figure 5(a)). Thus, ME could reduce ERK1/2 function by directly suppressing ERK1/2 expression. Additionally, phosphorylation of MAP kinases, 


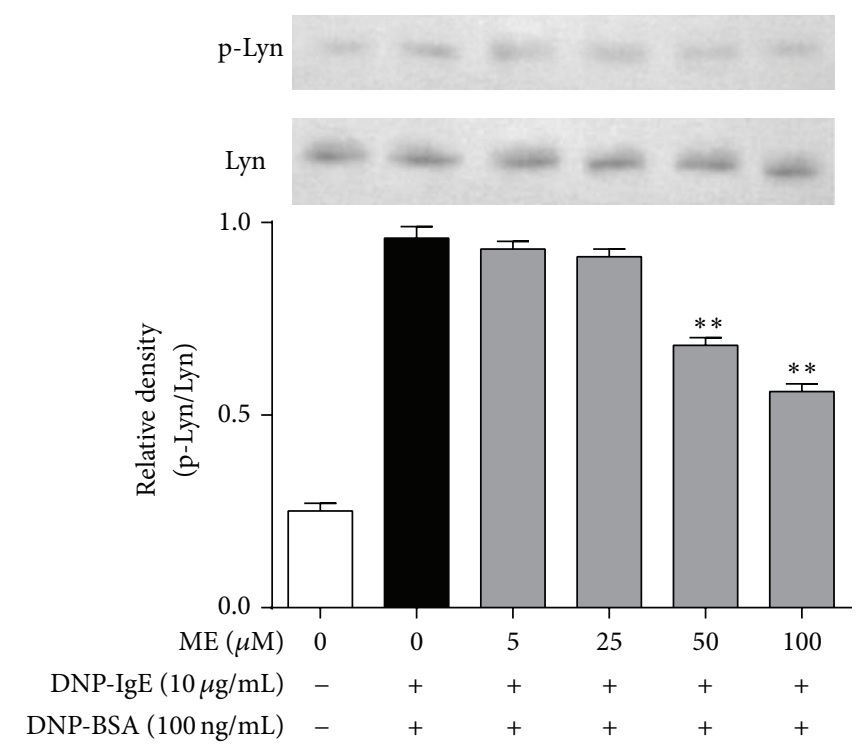

(a)

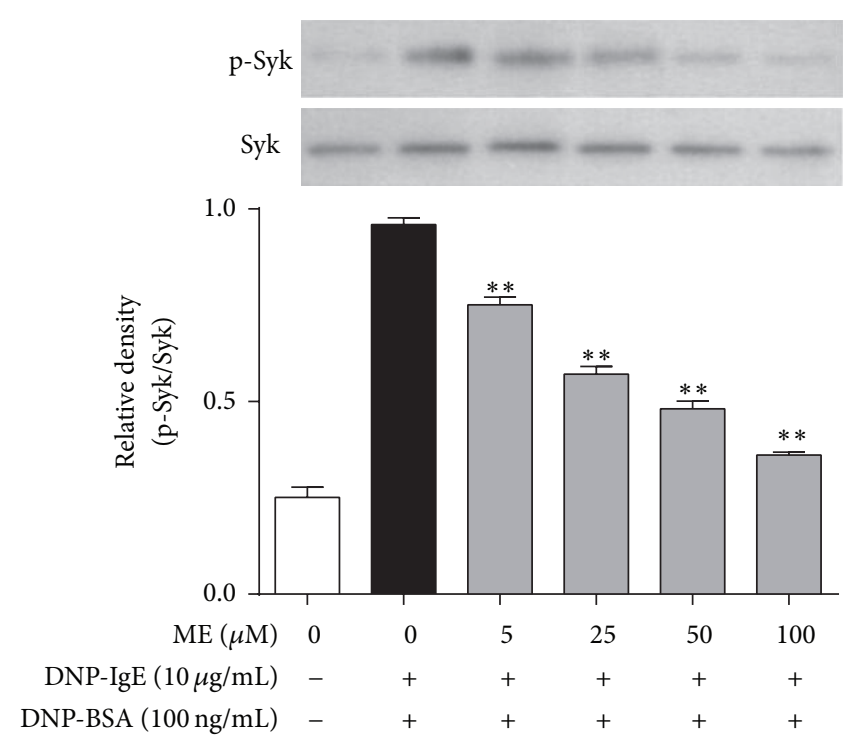

(b)

FIGURE 4: Effect of ME on early stage of FceRI cascade in IgE-activated RBL-2H3 cells. IgE-sensitized RBL-2H3 cells were exposed to ME $(0-100 \mu \mathrm{M})$ for $1 \mathrm{~h}$ and then stimulated by DNP-BSA $(100 \mathrm{ng} / \mathrm{mL})$ for $10 \mathrm{~min}$. The cells were rinsed with $1 \times$ PBS and lysed with cell lysis buffer. The expression of p-Lyn, Lyn, p-Syk, and Syk was determined as described in Section 2. Data represent the mean \pm SD of three independent experiments and differences between mean values were assessed by one-way ANOVA. ${ }^{*} P<0.05,{ }^{* *} P<0.01$ indicate significant differences compared with the DNP-BSA-treated group.

such as $\mathrm{p} 38$ or JNK, was also suppressed by ME, although p38 phosphorylation was more sensitive to ME (Figures 5(b) and $5(\mathrm{c}))$.

\section{Discussion}

The essential oil of Asiasari radix has many beneficial health effects, exhibiting anti-inflammatory, antibacterial, and antiallergy properties, as well as affecting the respiratory and circulatory systems [25]. Asiasari radix essential oils contain a considerable number of chemical ingredients, including ME, asarylketone, cineol, safrole, limonene, and eucarvone [26]. Previously, ME was reported to have beneficial effects on inflammation, ischemia, anaphylaxis, and nociception. Our present data demonstrate that $\mathrm{ME}$ exerts antiallergic effects in IgE-activated RBL-2H3 cells. ME significantly suppresses degranulation and proinflammatory cytokine release in antigen-sensitized mast cells. Several cytokines play critical roles in allergic inflammation. For example, TNF- $\alpha$, which is secreted from IgE-activated mast cells, plays an important role in allergic responses [27]. Therefore, the inhibitory effect of ME on TNF- $\alpha$ formation may indicate its added advantage as an antiallergy agent. During the pathogenesis of allergic disease, IL- 4 is crucial for the induction of IgE synthesis and mast cell development [28]. IL-4 also modulates the inflammatory response, owing to its ability to affect adhesion molecule expression and cytokine production in endothelial cells, and promotes growth and activation of neutrophils, mast cells, T cells, and eosinophils [29]. These results suggest that ME significantly inhibits mast cell degranulation and proinflammatory cytokine release.
One possible mechanism of ME-induced antiallergic activity may be its effect on the FceRI signal cascade. IgEinduced degranulation in mast cells is associated with activation of the FceRI receptor, and this activation induces the release of various inflammatory mediators, including TNF$\alpha$, leukotrienes, and prostaglandins via phosphorylation of the Lyn/Syk pathway [23]. In turn, the activation of Syk increases intracellular $\mathrm{Ca}^{2+}$ and the activation of the MAP kinase family [23]. Thus, Lyn and Syk are important intracellular mediators in early signaling following FceRI receptor activation. In the present study, Syk was markedly inhibited by ME, supporting the notion that it is a primary target of ME. In support of this observation, ME significantly reduced the phosphorylation of ERK1/2, p38, and JNK, which are downstream effectors of FceRI [23].

In the present study, $100 \mu \mathrm{M}$ ME obviously inhibited $\mathrm{CPLA}_{2}$ and 5-LO phosphorylation and decreased the formation of the $5-\mathrm{LO}$ products, $\mathrm{LTB}_{4}$ and $\mathrm{LTC}_{4}$. This effect may improve the antiallergy action of $\mathrm{ME}$, because $\mathrm{LTB}_{4}$ is a potent chemoattractant and activator of neutrophils and other immune cells in severe asthma $[30,31] . \mathrm{LTC}_{4}$ is a potent spasmogenic agent and an agonist of cysteinyl-LT receptors, which are known to induce chronic inflammatory reactions in allergic diseases [21]. Furthermore, ME also inhibited COX-2 expression and dramatically reduced the levels of the COX-2 products $\mathrm{PGE}_{2}$ and $\mathrm{PGD}_{2}$, which are enhanced in activated immune cells, including mast cells [20, 32]. The suppressive effects of $\mathrm{ME}$ on $\mathrm{PGE}_{2}$ formation may contribute to its increased antiallergic activity, as $\mathrm{PGE}_{2}$ may mediate asthma development and inflammation associated with IL-4 and IL-5, which are produced by helper T cells [32]. 


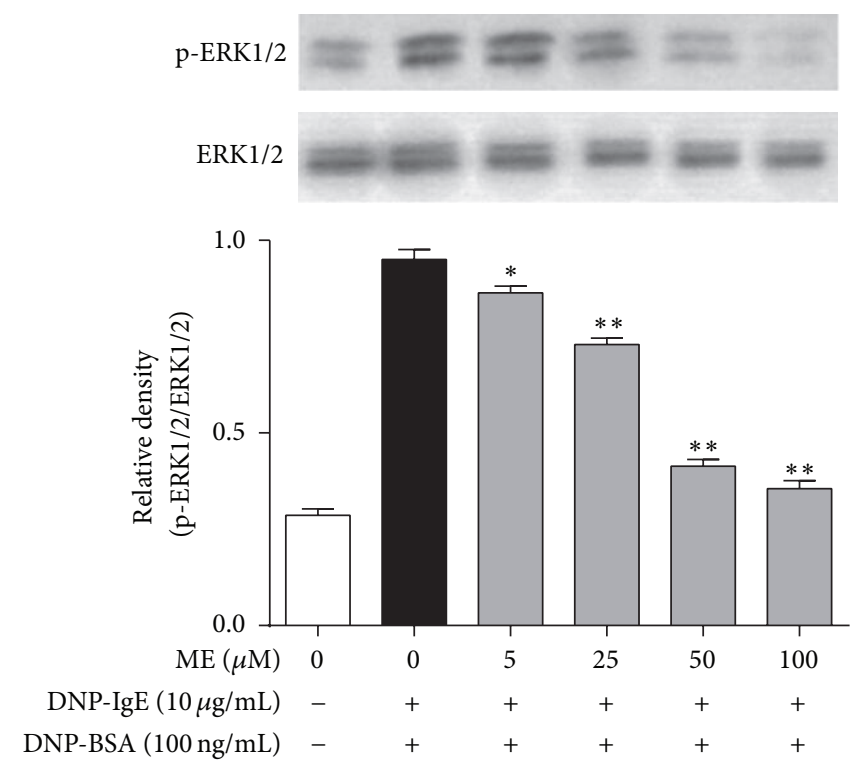

(a)

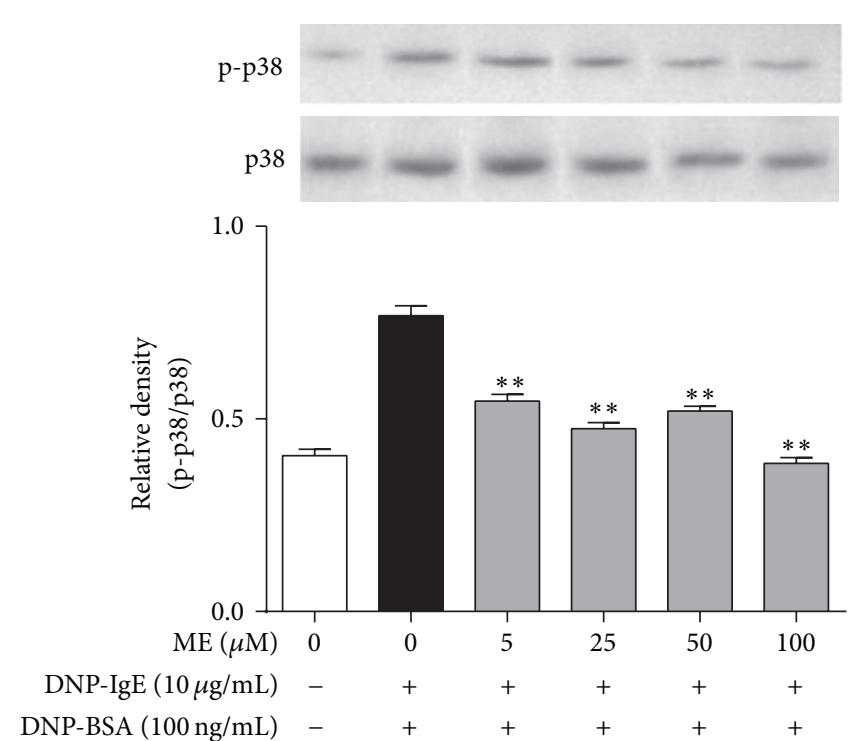

(b)

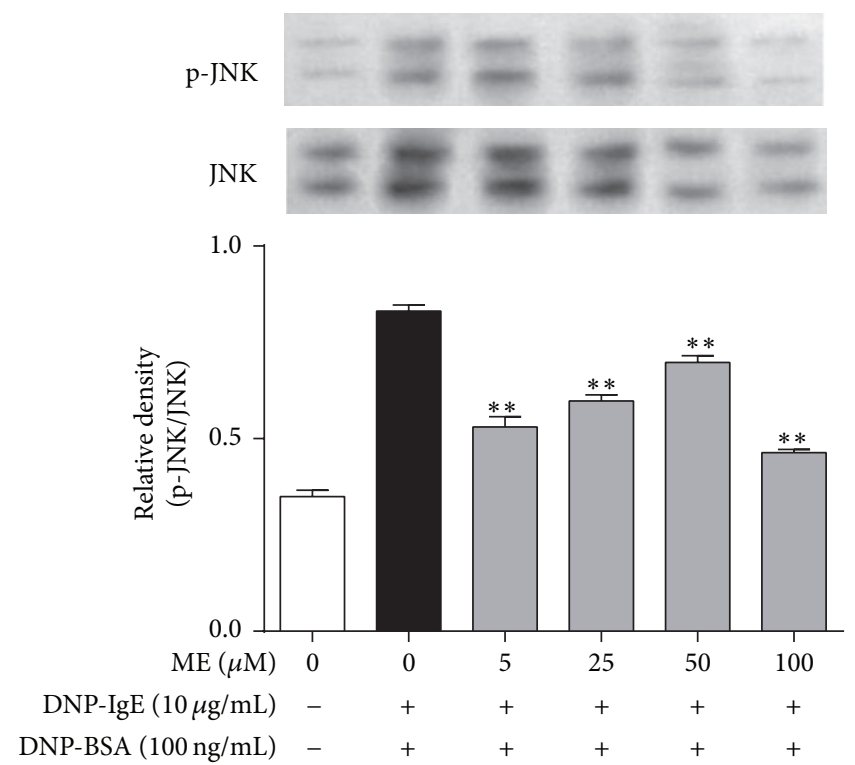

(c)

FIgURE 5: Effect of ME on MAP kinase pathway in IgE-activated RBL-2H3 cells. IgE-sensitized RBL-2H3 cells were exposed to ME (0$100 \mu \mathrm{M})$ for $1 \mathrm{~h}$ and then stimulated by DNP-HSA $(100 \mathrm{ng} / \mathrm{mL})$ for $10 \mathrm{~min}$. The cells were rinsed with $1 \times$ PBS and lysed with cell lysis buffer. The expression of p-ERK1/2, ERK1/2, p-p38, p38, p-JNK1/2, or JNK1/2 was determined as described in Section 2. Data represent the mean $\pm \mathrm{SD}$ of three independent experiments and differences between mean values were assessed by one-way ANOVA. ${ }^{*} P<0.05,{ }^{* *} P<0.01$ indicate significant differences compared with the DNP-BSA-treated group.

Moreover, the inhibitory effect of ME on $\mathrm{PGD}_{2}$ formation may add to the antiallergic action, as $\mathrm{PGD}_{2}$ is known to cause bronchoconstriction and vasodilation and increases capillary permeability and mucous production in asthma [20]. Collectively, these findings suggest that $\mathrm{ME}$ can reduce allergic reactions through suppression of $\mathrm{CPLA}_{2}$ and 5-LO activation and through inhibition of COX-2 activity. Taken together, ME can inhibit allergic reaction by suppressing the activation of Syk, ERK1/2, p38, and JNK and reducing the activity of the enzymes responsible for the biosynthesis of $\mathrm{PGD}_{2}$ and $\mathrm{LTB}_{4}$.
Further, these effects may be extended to anti-inflammatory effects on other cells or tissues. Additionally, the expression of TNF- $\alpha$ is associated with p38, JNK, and ERK1/2 activation in the FceRI receptor cascade in IgE-activated mast cells [23]. Therefore, the reduction of TNF- $\alpha$ formation by ME may provide an additional advantage to $\mathrm{ME}$ as an antiallergic agent.

In conclusion, the present study demonstrates that ME has antiallergic effects in IgE-activated RBL-2H3 cells. The mechanisms responsible for its antiallergic effects may 
involve multiple targets including Sky, ERK1/2, p38, JNK, $\mathrm{CPLA}_{2}, 5-\mathrm{LO}$, and COX-2. Such effects may provide further information for the application of $\mathrm{ME}$ as an antiallergic agent. Therefore, our future studies will focus on providing additional pharmacological evidence to demonstrate this possibility.

\section{Conflict of Interests}

The authors declare that they have no conflict of interests.

\section{Acknowledgments}

This research was supported by the Science and Technology Development Funding Foundation of Guangdong Province (Grant no. 2012A032400002), the Medical Scientific Research Foundation of Guangdong Province (B2013074), the National Natural Science Foundation of China (Grant no. 81202431), and the Natural Science Foundation of Guangdong Province (Grant no. S2012010009576).

\section{References}

[1] C. Flohr, R. J. Quinnell, and J. Britton, "Do helminth parasites protect against atopy and allergic disease?" Clinical and Experimental Allergy, vol. 39, no. 1, pp. 20-32, 2009.

[2] K. J. Erb, "Can helminths or helminth-derived products be used in humans to prevent or treat allergic diseases?" Trends in Immunology, vol. 30, no. 2, pp. 75-82, 2009.

[3] B. S. Bochner and R. P. Schleimer, "Mast cells, basophils, and eosinophils: distinct but overlapping pathways for recruitment," Immunological Reviews, vol. 179, pp. 5-15, 2001.

[4] S. J. Galli, "New concepts about the mast cell," The New England Journal of Medicine, vol. 328, no. 4, pp. 257-265, 1993.

[5] M. Nguyen, A. J. Pace, and B. H. Koller, "Age-induced reprogramming of mast cell degranulation," Journal of Immunology, vol. 175, no. 9, pp. 5701-5707, 2005.

[6] A. M. Gilfillan and C. Tkaczyk, "Integrated signalling pathways for mast-cell activation," Nature Reviews Immunology, vol. 6, no. 3, pp. 218-230, 2006.

[7] M. K. Church and F. Levi-Schaffer, "The human mast cell," Journal of Allergy and Clinical Immunology, vol. 99, no. 2, pp. 155-160, 1997.

[8] D. D. Metcalfe, M. Kaliner, and M. A. Donlon, "The mast cell," Critical Reviews in Immunology, vol. 3, no. 1, pp. 23-74, 1981.

[9] W. Duan and W. S. F. Wong, "Targeting mitogen-activated protein kinases for asthma," Current Drug Targets, vol. 7, no. 6, pp. 691-698, 2006.

[10] A. Lorentz, I. Klopp, T. Gebhardt, M. P. Manns, and S. C. Bischoff, "Role of activator protein 1, nuclear factor-kappaB, and nuclear factor of activated $\mathrm{T}$ cells in IgE receptor-mediated cytokine expression in mature human mast cells," Journal of Allergy and Clinical Immunology, vol. 111, no. 5, pp. 1062-1068, 2003.

[11] B. Frossi, J. Rivera, E. Hirsch, and C. Pucillo, "Selective activation of Fyn/PI3K and p38 MAPK regulates IL-4 production in BMMC under nontoxic stress condition," The Journal of Immunology, vol. 178, no. 4, pp. 2549-2555, 2007.

[12] Y. Kawakami, S. E. Hartman, P. M. Holland, J. A. Cooper, and T. Kawakami, "Multiple signaling pathways for the activation of JNK in mast cells: involvement of Bruton's tyrosine kinase, protein kinase C, and JNK kinases, SEK1 and MKK7," Journal of Immunology, vol. 161, no. 4, pp. 1795-1802, 1998.

[13] D. Hata, Y. Kawakami, N. Inagaki et al., "Involvement of Bruton's tyrosine kinase in FcepsilonRI-dependent mast cell degranulation and cytokine production," Journal of Experimental Medicine, vol. 187, no. 8, pp. 1235-1247, 1998.

[14] S. Yano, Y. Suzuki, M. Yuzurihara et al., "Antinociceptive effect of methyleugenol on formalin-induced hyperalgesia in mice," European Journal of Pharmacology, vol. 553, no. 1-3, pp. 99-103, 2006.

[15] K. Hashimoto, T. Yanagisawa, Y. Okui, Y. Ikeya, M. Maruno, and T. Fujita, "Studies on anti-allergic components in the roots of Asiasarum sieboldi," Planta Medica, vol. 60, no. 2, pp. 124-127, 1994.

[16] C. C. Lima, D. N. Criddle, A. N. Coelho-De-Souza, F. J. Q. Monte, M. Jaffar, and J. H. Leal-Cardoso, "Relaxant and antispasmodic actions of methyleugenol on guinea-pig isolated ileum," Planta Medica, vol. 66, no. 5, pp. 408-411, 2000.

[17] Y. K. Choi, G.-S. Cho, S. Hwang et al., "Methyleugenol reduces cerebral ischemic injury by suppression of oxidative injury and inflammation," Free Radical Research, vol. 44, no. 8, pp. 925-935, 2010.

[18] B. K. Shin, E. H. Lee, and H. M. Kim, "Suppression of Lhistidine decarboxylase mRNA expression by methyleugenol," Biochemical and Biophysical Research Communications, vol. 232, no. 1, pp. 188-191, 1997.

[19] M. Ishiyama, H. Tominaga, M. Shiga, K. Sasamoto, Y. Ohkura, and K. Ueno, "A combined assay of cell viability and in vitro cytotoxicity with a highly water-soluble tetrazolium salt, neutral red and crystal violet," Biological and Pharmaceutical Bulletin, vol. 19, no. 11, pp. 1518-1520, 1996.

[20] M. Arima and T. Fukuda, "Prostaglandin $\mathrm{D}_{2}$ and $\mathrm{T}_{H} 2$ inflammation in the pathogenesis of bronchial asthma," The Korean Journal of Internal Medicine, vol. 26, no. 1, pp. 8-18, 2011.

[21] E. Nettis, M. D’Erasmo, E. di Leo et al., “The employment of leukotriene antagonists in cutaneous diseases belonging to allergological field," Mediators of Inflammation, vol. 2010, Article ID 628171, 6 pages, 2010.

[22] Y. Kawakami, J. Kitaura, A. B. Satterthwaite et al., "Redundant and opposing functions of two tyrosine kinases, Btk and Lyn, in mast cell activation," Journal of Immunology, vol. 165, no. 3, pp. 1210-1219, 2000.

[23] K. Roth, W. M. Chen, and T. J. Lin, "Positive and negative regulatory mechanisms in high-affinity IgE receptor-mediated mast cell activation," Archivum Immunologiae et Therapiae Experimentalis, vol. 56, no. 6, pp. 385-399, 2008.

[24] Y. Kim, Y.-S. Lee, J.-H. Hahn et al., "Hyaluronic acid targets CD44 and inhibits FceRI signaling involving PKC $\delta$, Racl, ROS, and MAPK to exert anti-allergic effect," Molecular Immunology, vol. 45, no. 9, pp. 2537-2547, 2008.

[25] Y. S. Wang, Pharmacology and Application of Chinese Materia Medica, People's Health Publisher, Beijing, China, 1983.

[26] R. H. Zhou, Resource Science of Chinese Medicinal Materials, China Medical \& Pharmaceutical Sciences Press, Beijing, China, 1993.

[27] T. C. Theoharides and D. Kalogeromitros, "The critical role of mast cells in allergy and inflammation," Annals of the New York Academy of Sciences, vol. 1088, pp. 78-99, 2006.

[28] Y. Nabeshima, T. Hiragun, E. Morita, S. Mihara, Y. Kameyoshi, and M. Hide, "IL-4 modulates the histamine content of mast 
cells in a mast cell/fibroblast co-culture through a Stat6 signaling pathway in fibroblasts," FEBS Letters, vol. 579, no. 29, pp. 6653-6658, 2005.

[29] J.-L. Boulay and W. E. Paul, "The interleukin-4 family of lymphokines," Current Opinion in Immunology, vol. 4, no. 3, pp. 294-298, 1992.

[30] A. W. Ford-Hutchinson, M. A. Bray, M. V. Doig, M. E. Shipley, and M. J. H. Smith, "Leukotriene B, a potent chemokinetic and aggregating substance released from polymorphonuclear leukocytes," Nature, vol. 286, no. 5770, pp. 264-265, 1980.

[31] A. M. Tager and A. D. Luster, "BLT1 and BLT2: the leukotriene B(4) receptors," Prostaglandins Leukotrienes and Essential Fatty Acids, vol. 69, no. 2-3, pp. 123-134, 2003.

[32] T. C. T. M. van der Pouw Kraan, L. C. M. Boeije, R. J. T. Smeenk, J. Wijdenes, and L. A. Aarden, "Prostaglandin-E2 is a potent inhibitor of human interleukin 12 production," Journal of Experimental Medicine, vol. 181, no. 2, pp. 775-779, 1995. 


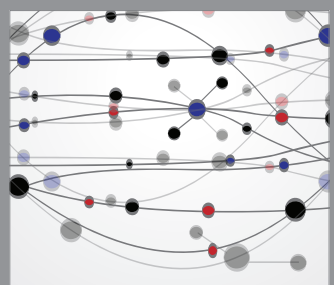

The Scientific World Journal
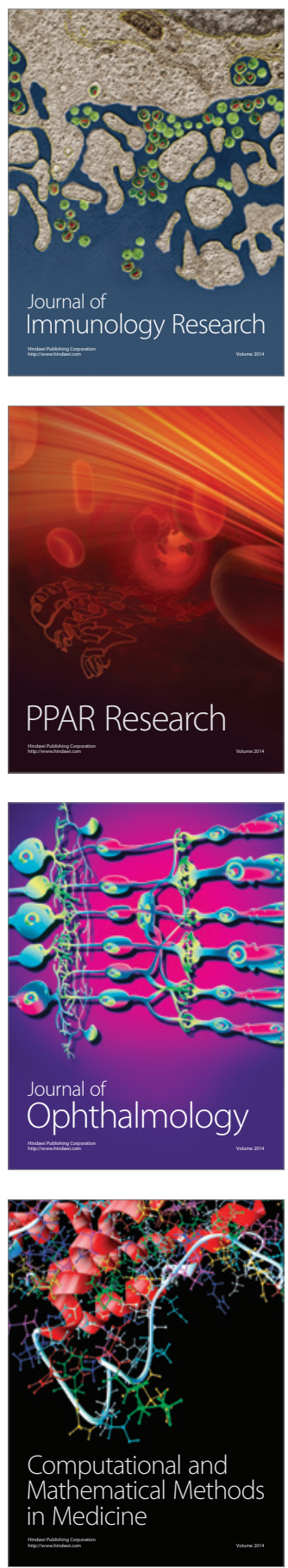

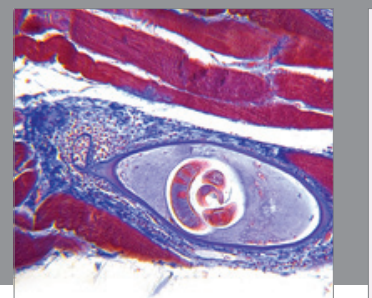

Gastroenterology

Research and Practice
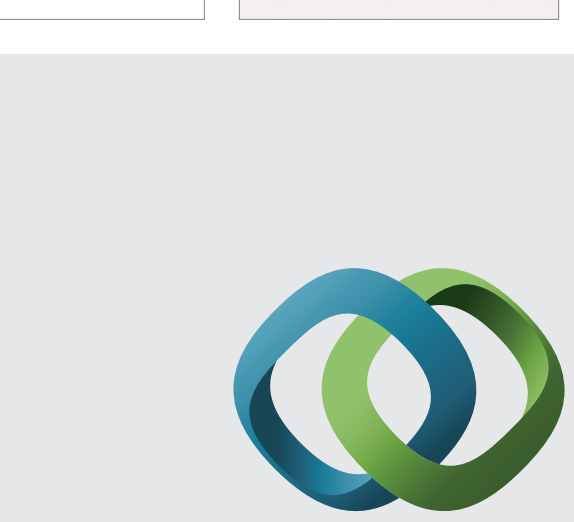

\section{Hindawi}

Submit your manuscripts at

http://www.hindawi.com
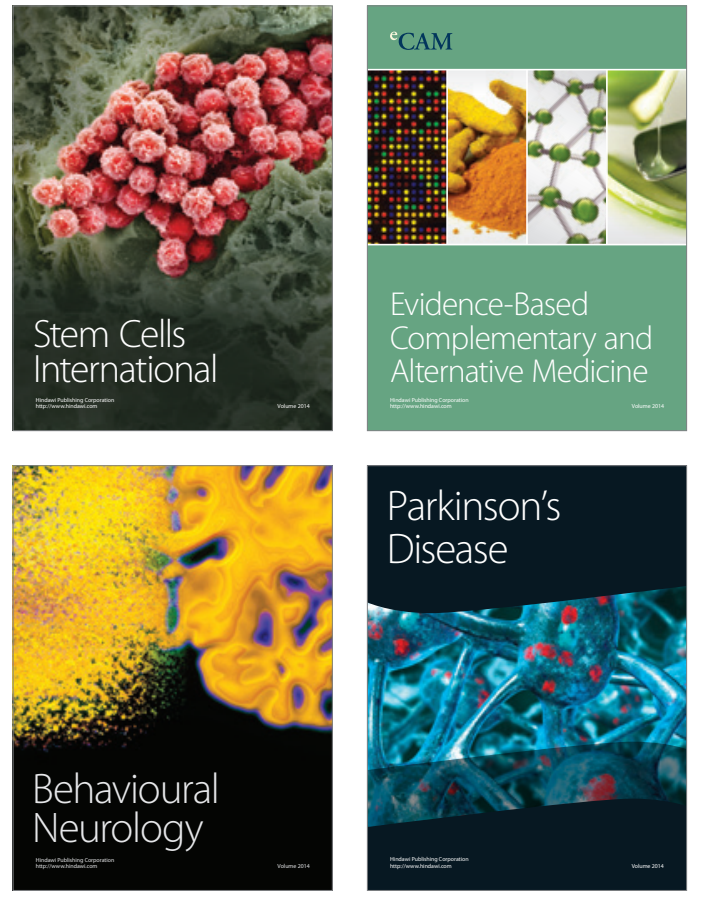
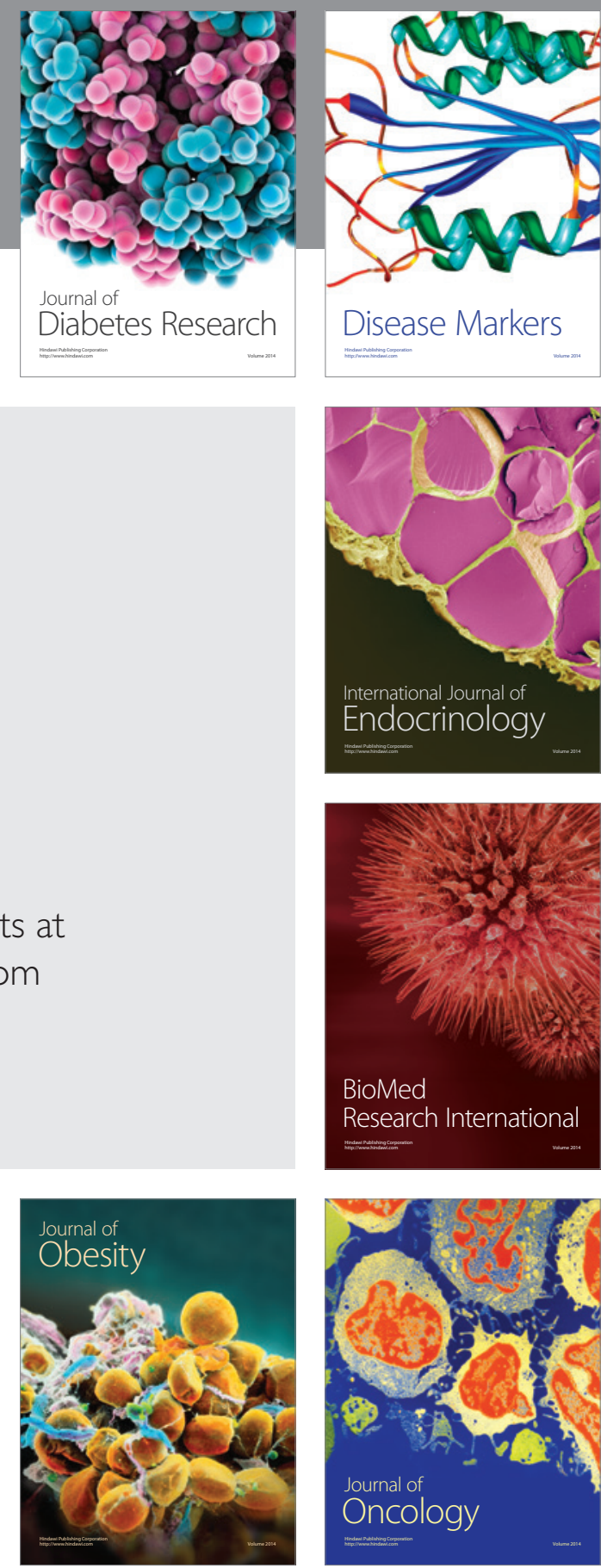

Disease Markers
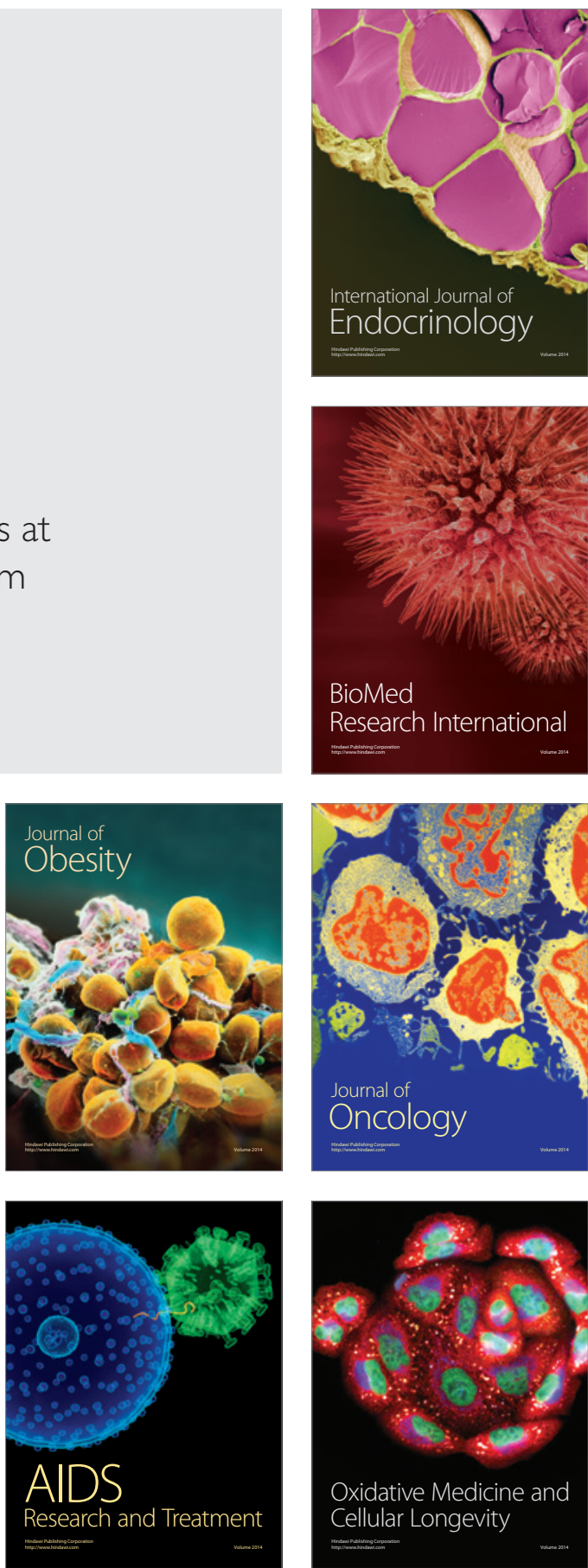